\title{
Serum Vascular Endothelial Growth Factor in Children with Beta Thalassemia Major
}

\author{
Authors \\ Reem A. Abdel Aziz ${ }^{1 \S}$, Gamal B. Mohamed ${ }^{1}$, Emad A. Abd El-Naeem², \\ Eman M. Sedek ${ }^{1}$. \\ ${ }^{1}$ Department of Pediatrics, Faculty of Medicine, Minia University, Egypt \\ ${ }^{2}$ Department of Clinical-pathology, Faculty of Medicine, Minia University, Egypt \\ ${ }^{\S}$ Corresponding Author \\ Reem A. Abdel Aziz \\ Email: reemabdelsalam3@gmail.com Mobile number: +201008326126
}

\begin{abstract}
Introduction: Beta-thalassemia major is an autosomal recessive hereditary anemia; patients frequently end up with iron overload because of hemolysis and repeated blood transfusion. Treatment with iron chelating therapy in patients with beta-thalassemia is considered the standard care, leading to improvement of morbidity and increased rate of survival. Vascular endothelial growth factor (VEGF), is a signal protein produced by cells that stimulates vasculogenesis and angiogenesis.

Aim of the work: is to assess serum Vascular Endothelial Growth Factor level in children with betathalassemia major as a marker of angiogenesis.

Methods: this study was conducted upon 100 children; 50 with B thalassemia major, 50 children as a control group. Complete blood count, serum ferritin and serum VEGF level were assessed in all children.

Results: Patients had significantly lower serum levels of hemoglobin and hematocrit than controls $(p<$ $0.001)$, and also had significantly higher serum levels of WBCs, platelets, ferritin and VEGF than controls ( $p<$ 0.001).Serum level of VEGF was significantly higher in splenectomized patients than in nonsplenectomized patients ( $p<0.001$ ).

Conclusion: Patients with beta thalassemia major had high levels of VEGF. The VEGF level was higher in splenectomised thalassemic patients than non splenectomized ones. Chelation starting age was positively correlated with VEGF level. VEGF is a reliable marker for prediction of thalassemic patients for chelation therapy.
\end{abstract}

Keywords: thalassemia, VEGF, chelation therapy, angiogenesis.

\section{Introduction}

Beta-thalassemia major is an autosomal recessive hereditary anemia, which is incurable, caused by defective synthesis of hemoglobin, ineffective erythropoiesis, and rapid erythrocyte breakdown [1].
Beta-thalassemia major patients frequently end up with iron overload because of hemolysis and repeated blood transfusion. Treatment with iron chelating therapy in patients with beta-thalassemia is considered the standard care, leading to improvement of morbidity and increased rate of survival $^{[2]}$. 
Endothelial cell proliferation plays a role in vascular injury repair and blood vessels formations. It is affected by plasma derived and blood cell derived component ${ }^{[3]}$.

Vascular endothelial growth factor (VEGF), originally known as vascular permeability factor (VPF), is a signal protein produced by cells that stimulates vasculogenesis and angiogenesis. It is a part of the system that restores the oxygen supply to tissues when blood circulation is inadequate. Serum concentration of VEGF is high in bronchial asthma and diabetes mellitus ${ }^{[4]}$.

VEGF's normal function is to create new blood vessels during embryonic development, new blood vessels after injury, muscle following exercise, and new vessels (collateral circulation) to bypass blocked vessels. ${ }^{[5]}$.

Tissue hypoxia is a major stimulus for the upregulation of VEGF and anemic patients have elevated levels of VEGF. This suggests that anemia might impact on the progression of angeiogenesis in malignant and benign diseases [6].

\section{Aim of the study}

The purpose of this work is to assess serum Vascular Endothelial Growth

Factor level in children with betathalassemia major as a marker of angiogenesis and to detect its relation with the chelation therapy.

\section{Materials and Method}

\section{Study design:}

This is a case - control comparative study.

\section{Study population:}

This study included 100 children divided into 2 groups:

Group I: 50 patients diagnosed as betathalassemia major. They were $29(58 \%)$ males and $21(42 \%)$ females aged from 2-12 years. Who presented to Pediatric Hematology Clinic, Minya University Hospital during the period from March 2016 to July 2016.

The mean of chelation starting age in patients was $4.65 \pm 0.36$ and range was $4-5$ years. Patients on chelation therapy were $40(80 \%)$. patients with splenectomy were 12 (24\%).

Group II: 50 apparently healthy subjects with matching age \& sex were included and served as a control group. They were 21 (42\%) males and 29 (58\%) females aged from 2-12 years.

\section{Ethical Approval:}

The goal and methodology of the study were described to all patients' parents after approval of hospital ethics committee. Verbal consents were taken from the parents in the study. The potential benefits and inconveniences of all aspects of the study were clearly stated to the parents.

Patients were selected on the basis of the following inclusion and exclusion criteria:

Clinically and laboratory diagnosed patients as Beta-thalassemia major, both patients receiving and not receiving chelation therapy, both splenectomised and non-splenectomized patients were included in this study.

Other causes of anemia, other chronic diseases (cardiac, renal, vascular), malignancy, and patients with other hemoglobinopathy were excluded from this study.

\section{All studied groups were subjected to:}

Full history taking: age and sex, history of consanguinity, similar family condition, age of diagnosis, age of onset of the chelation therapy, and whether splenectomized or not, Anthropometric measurements: weight in kilograms, height in centimeters and body mass index (BMI). BMI was calculated from the following formula; $\mathrm{BMI}=$ weight $(\mathrm{kg}) /$ height $(\mathrm{m})^{2}$. Complete Clinical Examination: presence of pallor, jaundice, mongoloid facies, organomegaly (hepatomegaly or splenomegaly), scar of splenectomy.

\section{Methodology}

All studied groups were subjected to the following investigations: Complete blood count by automated cell counters sysmex KX 21 (TAO, medical incorporation, japan), serum ferritin by enzyme immunoassay (EIA), hemoglobin Electrophoresis by using Beckman counter kits for patients only, and serum vascular endothelial growth factor by enzyme Immunoassay (EIA). 
Kits supplied by WKEA MED SUPPLIES CORP (WKEA).

Sampling and Storage: Three $\mathrm{ml}$ of venous blood were taken from all subjects Used as following:

$>$ One $\mathrm{ml}$ of venous blood on EDTA containing tube for CBC and hemoglobin electrophoresis.

Two $\mathrm{ml}$ of venous blood on a plain tube and samples were left to be clotted in the incubator and then centrifuged for 10 minutes at approximately 3000 g. Serum was separated and stored at $-70^{\circ} \mathrm{C}$ till time of assessment of serum ferritin and vascular endothelial growth factor.

\section{Vascular endothelial growth factor assays:}

The principle of the assay is to use Purified Human VEGF antibody to coat microtiter plate wells, make solid-phase antibody, then add VEGF to wells, combined antibody with enzyme labeled goat antiHuman become antibody - antigen - enzymeantibody complex, after washing completely, Add substrate which becomes blue color At HRP enzyme- catalyzed, reaction is terminated by the addition of a sulphuric acid solution and the color change is measured spectrophotometrically at a wave length of $450 \mathrm{~nm}$. The concentration ofVEGF in the samples is then determined by comparing the Optical Density (OD) of the samples to the standard curve.

\section{Statistical Method}

The collected data were coded, tabulated, and statistically analyzed using SPSS program (Statistical Package for Social Sciences) software version 20.

$>$ Descriptive statistics were done for numerical data by mean, standard deviation and minimum\& maximum of the range, while they were done for categorical data by number and percentage.

$>$ Analyses were done for parametric quantitative data between two groups using independent sample $t$ test.

Analyses were done for qualitative data using Chi square test.
$>$ Correlation between two quantitative variables was done by using Pearson's correlation coefficient and for qualitative ordinal variable by using non-parametric Spearman's rho correlation coefficient.

$>$ Correlation coefficient ranges from (0-1):weak $(r=0-0.24)$, fair $(r=0.25-0.49)$, moderate $(\mathrm{r}=0.5-0.74)$, strong $(\mathrm{r}=0.75-1)$

$>$ The level of significance was taken at $(\mathrm{P}$ value $<0.05$ )

ROC curve was done to terminate the cut off point, area under the curve (AUC), sensitivity, specificity, positive predicative value, negative predicative value, accuracy of valuable predicting beta thalassemia major patients on chelation therapy.

\section{Results}

This study included 100 children divided into 2 groups:

Group 1: 50 patients with beta-thalassemia major. They were 29 (58\%) males and 21 (42\%) females aged from 2-12 years, who presented to pediatric Hematology Clinic, Minya University Hospital during the period from March, 2016 to July, 2016.

Patients' mean age of diagnosis was $9.9 \pm 1.56$ and range was 7-12 months.

The mean of chelation starting age in patients was $4.65 \pm 0.36$ and range was $4-5$ years. Patients on chelation therapy were 40 (80\%). patients with splenectomy were 12 (24\%).

Group 2: 50 apparently healthy subjects with age \& sex matched were included and served as a control group. They were 21 (42\%) males and 29 (58\%) females aged from 2-12 years.

Height was significantly lower in patients than in controls $(p<0.001)$. Also, weight was lower in patients than in controls $(p=0.039)$.Patients with thalassemia had a higher body mass index than controls $(p<0.001)$. While there was no significant difference between two groups regarding age and sex (Table 1).

Regarding laboratory data, the serum levels of hemoglobin and hematocrit were significantly lower in patients than in the controls $(\mathrm{p}<0.001)$. 


\section{JMSCR Vol||04||Issue||12||Page 14955-14963||December}

While, the serum levels of WBCs, platelets and ferritin were significantly higher in patients than in controls $(\mathrm{p}<0.001)$ (Table 2$)$.

Regarding serum level of VEGF, it was significantly higher in patients $(838.7 \pm 278.16)$ than in controls $(152.06 \pm 64.68)(\mathrm{p}<0.001)$ (Table 2). Also, it was found that serum level of VEGF was significantly higher in splenoctomized patients $(1171.83 \pm 55.77)$ than in nonsplenectomized patients $(733.5 \pm 232.77) \quad(\mathrm{p}<$ 0.001) (Table 3).

VEGF showed a significant positive correlation with the age of onset of chelation therapy, platelets, chelation therapy, and splenectomy $(\mathrm{P}<$ 0.001) (Table 4).

Chelation therapy should be started when VEGF $>482 \mathrm{pg} / \mathrm{ml}$ as ROC curve revealed that the Cut off point $>482 \mathrm{pg} / \mathrm{ml}$ and the area under the curve $($ AUC $)=1($ sensitivity $=100$, Specificity $=100)$ (Table 5) (Figure 1).

Table 1: Demographic data of the studied groups

\begin{tabular}{|l||c||c||c||}
\hline & $\begin{array}{c}\text { Control } \\
(\mathrm{n}=50)\end{array}$ & $\begin{array}{c}\text { Thalassemia } \\
(\mathrm{n}=50)\end{array}$ & P value \\
\hline \hline Age & $(2-12)$ & $(2-12)$ & 0.134 \\
Range & $6.74 \pm 3.08$ & $7.67 \pm 3.05$ & \\
Mean \pm SD & & & \\
\hline Sex & $21(42.5 \%)$ & $29(58 \%)$ & 0.110 \\
Male & $29(57.5 \%)$ & $21(42 \%)$ & \\
Female & & & \\
\hline \hline Weight & $(12-33)$ & $(7-25)$ & $0.039^{*}$ \\
Range & $20.44 \pm 6.44$ & $17.94 \pm 5.48$ & \\
Mean \pm SD & & & \\
\hline \hline Height & $(85-145)$ & $(75-105)$ & $<0.001^{*}$ \\
Range & $11.34 \pm 19.01$ & $88 \pm 8.74$ & \\
Mean \pm SD & & & \\
\hline \hline BMI & $(14.79-18.52)$ & $(12.44-28.4)$ & $<0.001^{*}$ \\
Range & $16.19 \pm 0.89$ & $22.48 \pm 4.23$ & \\
Mean \pm SD & &
\end{tabular}

Table 2: Comparison between patients and control group regarding laboratory data

\begin{tabular}{|c|c|c|c|}
\hline & $\begin{array}{l}\text { Control } \\
(\mathrm{n}=50)\end{array}$ & $\begin{array}{c}\text { Thalassemia } \\
(\mathrm{n}=50)\end{array}$ & $\mathrm{P}$ value \\
\hline $\begin{array}{l}\mathrm{Hb} \\
\text { Range } \\
\text { Mean } \pm \mathrm{SD}\end{array}$ & $\begin{array}{c}(12-13.5) \\
12.86 \pm 0.49\end{array}$ & $\begin{array}{c}(5-7) \\
6.11 \pm 0.68\end{array}$ & $<0.001 *$ \\
\hline $\begin{array}{l}\text { Hematocrite } \\
\text { Range } \\
\text { Mean } \pm \text { SD }\end{array}$ & $\begin{array}{c}(40-45) \\
42.8 \pm 1.67\end{array}$ & $\begin{array}{c}(20-35) \\
27.68 \pm 3.87\end{array}$ & $<0.001 *$ \\
\hline $\begin{array}{l}\text { WBCs } \\
\text { Range }\end{array}$ & $(4.3-10)$ & $(5-10.5)$ & $<0.001 *$ \\
\hline
\end{tabular}

\begin{tabular}{|l||c|c||c||}
\hline \hline Mean \pm SD & $6.48 \pm 1.54$ & $7.73 \pm 1.41$ & \\
\hline \hline Platelets & & & \\
Range & $(160-280)$ & $(400-935)$ & $<0.001^{*}$ \\
Mean \pm SD & $223.9 \pm 34.51$ & $721.92 \pm 188.53$ & \\
\hline \hline Serum ferritin & & & \\
Range & $(100-300)$ & $(400-700)$ & $<0.001^{*}$ \\
Mean \pm SD & $218.2 \pm 39.72$ & $566 \pm 108.06$ & \\
\hline \hline Serum VEGF & & & \\
Range & $(84-250)$ & $(329-1200)$ & $<0.001^{*}$ \\
Mean \pm SD & $152.06 \pm 64.68$ & $838.7 \pm 278.16$ & \\
\hline
\end{tabular}

Table 3: Comparison between splenectomized and non-splenectomized patients regarding serum VEGF

\begin{tabular}{|l||c||c||c||}
\hline \multirow{2}{*}{} & \multicolumn{2}{c||}{ Splenectomy } & \multirow{2}{*||}{ P value } \\
\cline { 2 - 3 } & $\begin{array}{c}\text { No } \\
(\mathrm{n}=38)\end{array}$ & $\begin{array}{c}\text { Yes } \\
(\mathrm{n}=12)\end{array}$ & \\
\hline \hline Serum & & & \\
VEGF & $(329-1000)$ & $(100-1200)$ & $<0.001 *$ \\
Range & $733.5 \pm 232.77$ & $1171.83 \pm 55.77$ & \\
Mean \pm SD & & \\
\hline
\end{tabular}

Table 4: Correlation between serum VEGF and some clinical, laboratory data

\begin{tabular}{||l||c|c||}
\hline \multirow{2}{*}{} & \multicolumn{2}{c|}{ Serum VEGF } \\
\cline { 2 - 3 } & $\mathrm{r}$ & P value \\
\hline \hline${ }^{(1)}$ Age at diagnosis & 0.151 & 0.297 \\
\hline \hline${ }^{(1)}$ Age at chelation onset & 0.914 & $<0.001^{*}$ \\
\hline \hline${ }^{(1)}$ Age & 0.153 & 0.289 \\
\hline \hline${ }^{(1)}$ Weight & 0.133 & 0.356 \\
\hline \hline${ }^{(1)}$ Height & 0.126 & 0.385 \\
\hline \hline${ }^{(1)}$ BMI & 0.117 & 0.418 \\
\hline \hline${ }^{(1)}$ HB & -0.064 & 0.660 \\
\hline \hline${ }^{(1)}$ Hematocrite & 0.032 & 0.823 \\
\hline \hline${ }^{(1)}$ WBCs & 0.071 & 0.625 \\
\hline${ }^{(1)}$ Platelets & 0.980 & $<0.001^{*}$ \\
\hline \hline${ }^{(1)}$ Serum ferritin & 0.077 & 0.593 \\
\hline${ }^{(2)}$ Chelation therapy & 0.694 & $<0.001^{*}$ \\
\hline${ }^{(2)}$ Splenectomy & 0.732 & $<0.001^{*}$ \\
\hline
\end{tabular}

Table 5: ROC curve analysis of VEGF for prediction of patients on chelation therapy.

\begin{tabular}{|l|l|l|l|l|l|l|l|l|}
\hline $\begin{array}{l}\text { Vari } \\
\text { able }\end{array}$ & $\begin{array}{l}\text { Cut } \\
\text { off } \\
\text { poi } \\
\text { nt }\end{array}$ & $\begin{array}{l}\text { A } \\
\text { U } \\
\text { C }\end{array}$ & $\begin{array}{l}\text { P } \\
\text { valu } \\
\text { e }\end{array}$ & $\begin{array}{l}\text { Sensiti } \\
\text { vity }\end{array}$ & $\begin{array}{l}\text { Specif } \\
\text { icity }\end{array}$ & $\begin{array}{l}\text { PP } \\
\text { V }\end{array}$ & $\begin{array}{l}\text { NP } \\
\text { V }\end{array}$ & $\begin{array}{l}\text { Accur } \\
\text { acy }\end{array}$ \\
\hline $\begin{array}{l}\text { VEG } \\
\text { F }\end{array}$ & $\begin{array}{l}>48 \\
\text { pg/ } \\
\text { ml }\end{array}$ & 1 & $\begin{array}{l}<0.0 \\
01 *\end{array}$ & 100 & 100 & $\begin{array}{l}10 \\
0\end{array}$ & $\begin{array}{l}10 \\
0\end{array}$ & 100 \\
\hline
\end{tabular}




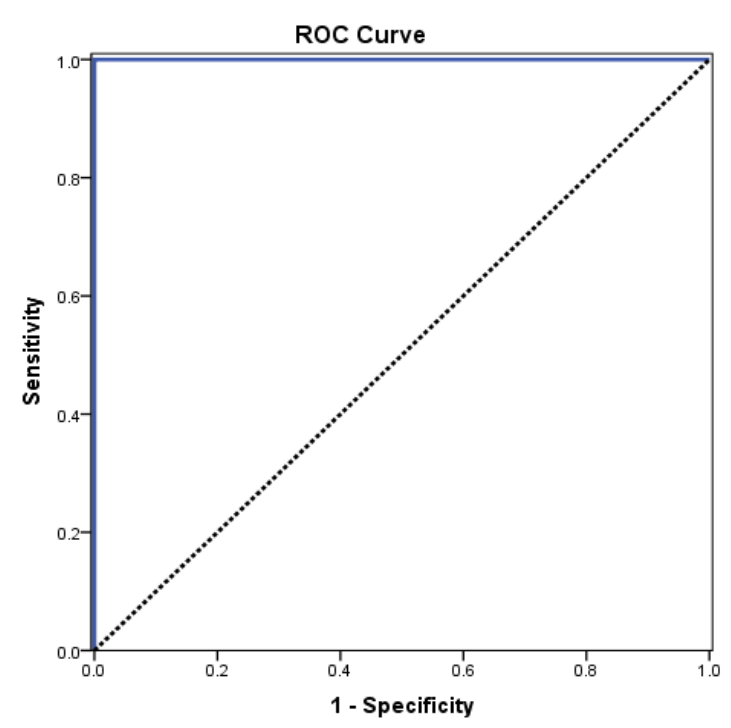

Figure (1): ROC curve analysis of VEGF for prediction of patients on chelation therapy.

\section{Discussion}

Beta-thalassemia major patients frequently end up with iron overload because of hemolysis and repeated blood transfusion. Treatment with iron chelating therapy in patients with beta-thalassemia is considered the standard care, leading to improvement of morbidity and increased rate of survival ${ }^{[2]}$.

Inflammation is known to have an important role in the pathogenesis of thalassemia. A chronic inflammatory state is present in these patients ${ }^{[7]}$.

Endothelial activation is also believed to play an important role in the pathophysiology of thalassemia, through inflammation and thrombosis ${ }^{[8]}$.

Angiogenesis, or the growth of new blood vessels, is important for wound healing and for restoring blood flow to tissues after injury or insult. In normal physiology, inhibitors and angiogenic growth factors, such as vascular endothelial growth factor (VEGF), regulate angiogenesis. When regulation fails, blood vessels are formed excessively or insufficiently ${ }^{[9]}$.

VEGF is mitogenic for endothelial cells and promotes vascular leakage. Besides its activity on endothelial cell proliferation, VEGF has synergistic activity with tumor necrosis factor (TNF) in inducing procoagulant activity of endothelial cells, promotes migration of monocytes across endothelial cells monolayers, and causes Von Willebrand factor release. Thus, VEGF affects endothelial functions related both to angiogenesis and to inflammation and thrombosis [10].

This study was done on 50 patients diagnosed as beta-thalassemia major aiming to assess serum VEGF level as a marker of angiogenesis in children with beta-thalassemia major and the possible risk factors related to VEGF level in those patients.

This study also included 50 apparently healthy subjects with matching age \& sex as a control group.

In this study, the anthropometric measurements including height was significantly lower in patients than controls $(\mathrm{p}<0.001)$. Also, weight was lower in patients than controls $(p=0.039)$, while B.M.I was significantly higher in patients than in controls $(\mathrm{p}<0.001)$.

This is in agreement with the study done by De Sanctis et al who reported that growth retardation in children with beta-thalassemia major is multifactorial. Key contributing factors to stunted growth in patients with beta thalassemia major include chronic anemia, transfusion-related iron overload and chelation toxicity. Other contributing factors include hypothyroidism, hypogonadism, Growth hormone deficiency/insufficiency, zinc deficiency, chronic liver disease, under nutrition, and psychosocial stress. Malnutrition is a significant cause of growth retardation in thalassemic children living in poor countries. In these children, inadequate nutrient intake (zinc, folic acid, vitamin D, carotenoids, and retinol binding proteins) contribute significantly to their growth impairment ${ }^{[11]}$.

In this study, white blood cells were significantly higher in patient group than the control group $(p<0.001)$. This is in agreement with the study done by Elsayh et al who reported that It has been observed that increased susceptibility of betathalassemia major patients to infectious diseases due to abnormalities of the immune system, which is evident by the systemic inflammation and immune deficiency. So, beta-thalassemia major patients had significantly higher total leukocytes, 
neutrophils and lymphocytes compared with controls $^{[12]}$.

In this current study, platelets count were significantly increased in patients in comparison to their corresponding control group ( $\mathrm{p}<0.001)$.

This is in agreement with the study of Chaudhary et alwho reported that it has been observed that in beta-thalassemia major, platelets are activated by free radical from hemoglobin, RBC phospholipids, thrombin, and micro particles. Then, after their activation, platelets bind to proteins $\mathrm{S}$ and $\mathrm{C}$, release thromboxane A2 (TXA2), and form micro particles of platelets. Iron overload is also present in beta-thalassemia major. Vitamin $\mathrm{C}$ is decreased due to this iron overload, which may result in platelet defect. On the other hand, this iron overload decreases lipid peroxide, which leads to release of TXA2 from platelets. Iron overload creates oxidative stress which causes vascular injury, which is itself increased by hemolysis due to hypoxia. As a result of vascular injury, prostacyclin is released. Prostacyclin and TXA2 result in clumping of platelets with vessel wall ${ }^{[13]}$. In this study, serum ferritin levels were significantly higher in patients than in controls $(p<0.001)$ This is in agreement with the study of Shahramianet al who reported that It has been observed that iron overload is caused by two mechanisms: blood transfusion and inadequate erythropoiesis. In beta-thalassemia major, Growth differentiation factor 15 (GDF15) proteins, which is the result of mutations in such patients, works as the inhibitor of peptide-Hepcidin hormone and sends it's reducing signal to the liver. Following Hepcidin reduction, iron absorption from the diet is increased by Ferroportin. Therefore, deficient erythrocyte built in the spleen is trapped, resulting in iron release which eventually leads to an increase in ferritin ${ }^{[14]}$.

In this study, patients with beta-thalassemia major had significantly higher VEGF level (mean: $838.7 \pm 278.16)$ compared to control group (mean:152.06 \pm 64.68$)$ with $(\mathrm{p}<0.001)$

Farokhi et al and Fahmey et al reported that VEGF level was significantly higher in patients with beta-thalassemia major than healthy controls $\mathrm{p}=0.037$ and $\mathrm{p}=0.001$ respectively. This is due to thalassemia patients had increased levels of angiogenic cytokines (such as VEGF, basic fibroblast growth factor, angiogenin, angiopoietin) compared with healthy controls ${ }^{[15,16]}$.

In our study, there was a significant difference in VEGF level between splenectomized and nonsplenectomized thalassemic patients $(\mathrm{p}<0.001)$ being higher in patients underwent splenectomy (mean: 1171.83 \pm 55.77$)$ than non-splenectomized patients (mean: $733.5 \pm 232.77$ ). Also, there was a significant positive correlation between splenectomy and serum level of VEGF in beta thalassemia major $(r=0.732, p<0.001)$

This is in agreement with the study done by Farokhi et al who reported that Serum VEGF level was significantly higher in splenectomized patients $(\mathrm{P}=0.006)^{[15]}$.

Fahmey et al reported that VEGF level was also higher in splenectomised thalassemic patients than non-splenectomized ones $(\mathrm{p}=0.001)^{[16]}$.

Olgar et al reported that VEGF level has a significant elevation in patients with beta thalassemia major who underwent splenectomy than non-splenectomized ones. This is may be due to patients who underwent splenectomy, had higher platelet count in their peripheral blood, and platelets are source of VEGF and secrete it ${ }^{[17]}$.

Shitrit et al who reported that splenectomized patients have a higher platelets count which act as a reservoir for VEGF ${ }^{[3]}$.

In our study, there was a significant correlation between VEGF and chelation starting age $(\mathrm{r}=0.914, \quad \mathrm{p}<0.001) \quad$ among beta-thalassemia patients, it means: early starting chelation age will decrease the level of VEGF. Olgar et al reported that there were positive correlations between VEGF levels and chelation starting age; so, the early use of chelation therapy will help to decrease angiogenesis ${ }^{[17]}$.

This finding is in contrast with that of Farokhi et al., 2015 who found that there was insignificant correlation between serum VEGF and chelation starting age $(p=0.737)$. This may be due to difference in the mean age of beginning iron 
chelation therapy $(4.65 \pm 0.36$ in our study and $5.21 \pm 4.12$ in the other study).

In our study, we found a significant correlation between platelets count and serum level of VEGF in beta-thalassemia major $(\mathrm{r}=0.980, \mathrm{p}<0.001)$. This was proved by Fahmey et al who reported that there was a significant correlation between platelets count and serum level of VEGF in beta thalassemia major ${ }^{[16]}$.

Also, Blann et al reported that VEGF was correlated positively with platelet count and soluble P-selectin which is one of platelet activation marker ${ }^{[18]}$.

Our finding is in contrast with the study done by Farokhi et al., 2015 who reported that there was not a significant correlation between platelet count and serum VEGF level. This may be due to low sample size (36 patients with beta-thalassemia major and 26 healthy people).

In this study, there was no significant correlation between VEGF level and weight, height, BMI in all patients $(\mathrm{p}=0.356, \mathrm{p}=0.385, \mathrm{p}=0.418)$ respectively. This may be due to that there were no overweight or obese patients among our thalassemic cases. Although, Silha et al reported that the obesity was associated with expansion of the capillary bed in regional fat depots. Adipose tissue contains a bundant endothelial cells and these cells, adipocytes or other cell types present in adipose tissue secrete VEGF and other angiogenic factors ${ }^{[19]}$.

In our study, there were no significant correlations between VEGF levels with hemoglobin and hematocrite in thalassemia patients $(p=0.660$, $\mathrm{p}=0.823$ ) respectively.

This was proved by Farokhi et al who reported that there were no significant correlation between VEGF levels with hemoglobin and hematocrite in thalassemia patients. This is probably because the anemia was not sever enough to induce tissue hypoxia $^{[15]}$.

Also, Fahmey et al who reported that there were no significant correlation between VEGF levels with hemoglobin and hematocrite in thalassemia patients, which might be due to the fact that those patients were on regular blood transfusion ${ }^{[16]}$.
In this study there was no significant correlation between VEGF level and serum ferritin level in patients $(\mathrm{p}=0.593)$.

Farokhi et al and Fahmey et al reported that there wasn't a significant correlation between VEGF and ferritin levels ${ }^{[15,16]}$.

Also, Olgar et al., 2010 reported that VEGF level was not affected by ferritin level and they couldn't find any relationship between iron load and VEGF levels. However, iron plays a fundamental role in cellular proliferation and copper has been shown to be a significant co-factor for angiogenesis. It has been suspected that iron chelation suppresses several angiogenic mediators, including vascular endothelial growth factor-1, fibroblast growth factor-1, interleukin (IL)-1, IL-6, IL-8, and nuclear factor- $\mathrm{B}^{[17]}$.

The lack of correlation between serum ferritin and angiogenesis might be due to chelation therapy and also this may be due to a higher level of angiogenic cytokines such as vascular endothelial growth factor (VEGF), basic fibroblast growth factor (bFGF), angiogenin (ANG), angiopoietin (Angp)-1 and -2 among patients with beta thalassemia major, but with no changes in these angiogenic cytokines after chelation therapy ${ }^{[16]}$.

As shown ROC curve analysis of VEGF $($ sensitivity $=100, \quad$ specificity $=100) \quad$ chelation therapy should be started when VEGF $>482$ $\mathrm{pg} / \mathrm{ml}$. No previous studies were done regarding the cut-off point of VEGF.

\section{Conclusion}

Patients with beta thalassemia major had high levels of VEGF. The VEGF level was higher in splenectomised thalassemic patients than non splenectomized ones. Chelation starting age was positively correlated with VEGF level. VEGF is a reliable marker for prediction of thalassemic patients for chelation therapy.

\section{Declaration}

\section{Competing Interests}

There are no any financial or non-financial competing interests to declare in relation to this manuscript. 


\section{Compliance with ethical standards}

Ethical approval:

Informed consents were obtained from all individuals' participants included in this study. The study was done according to the rules of the Local Ethics Committee of Faculty of Medicine, Minia University, Egypt.

Conflict of interest: All authors declare that there is no conflict of interest.

Funding: This research did not receive any specific grant from any funding agency in the public, commercial, or not-for-profit sector.

\section{Acknowledgements}

Authors wish to thank all staff of the Hematology Clinic of Minia University Hospitals for their assistance during the data collection and follow up of patients.

\section{References}

1. Pirinccioglu AG, Deniz T, Gokalp D, Beyazit N, Haspolat K, Soker M. Assessment of thyroid function in children aged 1-13 years with Beta-thalassemia major. Iran J Pediatr. 2011;21(1):77-82.

2. Garadah TS, Mahdi NA, Jaradat AM, Hasan ZA, Nagalla DS. Thyroid function status and echocardiographic abnormalities in patients with Beta thalassemia major in Bahrain. Clin Med Insights Cardiol. 2013;7:21-27.

3. Shitrit D, Tamary H, Koren A, Levin C, Bargil-Shitrit A, Sulkes J, Kramer MR. Correlation of vascular endothelial growth factor with the severity of thalassemia intermedia. Blood Coagul Fibrinolysis. 2008;19(7):611-614.

4. Johnson, K.E., and Wilgus, T.A. Vascular Endothelial Growth Factor and Angiogenesis in the Regulation of Cutaneous Wound Repair. Advances in Wound Care. 2014;3(10):647-661.

5. Palmer, Biff F.; Clegg, Deborah J. Oxygen sensing and metabolic homeostasis. Molecular and Cellular Endocrinology. 2014;397(1-2):51-58.
6. Dunst J, Becker A, Lautenschläger C, Markau S, Becker H, Fischer K, Haensgen G. Anemia and elevated systemic levels of vascular endothelial growth factor (VEGF). Strahlenther Onkol. 2002;178 (8):436-441.

7. Kanavaki I, Makrythanasis P, Lazaropoulou C, Tsironi M, Kattamis A, Rombos I, Papassotiriou I. Soluble endothelial adhesion molecules and inflammation markers in patients with beta-thalassemia intermedia. Blood Cells Mol Dis. 2009;43(3):230-234.

8. Aggeli C, Antoniades C, Cosma C, Chrysohoou C, Tousoulis D, Ladis V, Karageorga M, Pitsavos C, Stefanadis C. Endothelial dysfunction and inflammatory process in transfusion-dependent patients with beta-thalassemia major. Int J Cardiol. 2005;105(1):80-84.

9. Birk DM, Barbato J, Mureebe L, Chaer RA. Current insights on the biology and clinical aspects of VEGF regulation. Vasc Endovascular Surg. 2009;42(6):517-530.

10. Karamysheva A.F. Mechanisms of Angiogenesis. Biochemistry (Moscow). 2008;73(7):751-762.

11. De Sanctis V, Soliman AT, Elsedfy H, Skordis N, Kattamis C, Angastiniotis M, Karimi M, Yassin MM, El Awwa A, Stoeva I, Raiola G, Galati MC, Bedair EM, Fiscina B, El Kholy M. Growth and endocrine disorders in thalassemia: The international network on endocrine complications in thalassemia (I-CET) position statement and guidelines. Indian $\mathbf{J}$ EndocrinolMetab. 2013;17(1):8-18.

12. Elsayh KI, Mohammed WS, Zahran AM, Saad K. Leukocytes apoptosis and adipocytokines in children with beta thalassemia major. ClinExp Med. 2016;16(3):345-350.

13. Chaudhary HT, Ahmad N. Frequency of platelet aggregation defects in children suffering fromg $\beta$-thalassemia. Saudi J Health Sci. 2012;1(2):92-98. 
14. Shahramian I, Razzaghian M, Ramazani AA, Ahmadi GA, Noori NM, Rezae AR. The Correlation between Troponin and Ferritin Serum Levels in the Patients with Major Beta-Thalassemia. IntCardiovasc Res J. 2013;7(2):51-55.

15. Farokhi F, Razaviyan J, kosaryan M, Roudbari M, Reykande SE, Aliasghariyan A, Dehghani M . The relationship between serum vascular endothelial growth factor (SVEGF) and beta thalassemia major. Int J Med Invest. 2015;4(3):289-292.

16. Fahmey SS, Naguib HF, Abdelshafy SS, Alashry RE. Vascular endothelial growth factor in children with thalassemia major. Mediterr J Hematol Infect Dis. 2013;5(1):p.2013044.

17. Olgar S, Kara A, Hicyilmaz H, Balta N, Canatan D. Evaluation of angiogenesis with vascular endothelial growth factor in patients. Pediatr Int. 2010;52(2):247-251.

18. Blann A.D., Mohan J.S., Bareford D. and Lip G. Soluble P- selectin and vascular endothelial growth factor in steady state sickle cell disease: relationship to genotype. J. Thromb Thrombolysis. 2008;25(2):185-189.

19. Silha J.V., Krsek M., Sucharda P. and Murphy L.J. Angiogenic factors are elevated in overweight and obese individuals. Int. J. Obes. (Lond). 2005;29(11):1308-1314. 